Contents lists available at Џournal IICET

JPPI (Jurnal Penelitian Pendidikan Indonesia)

ISSN: 2502-8103 (Print) ISSN: 2477-8524 (Electronic)

\title{
The reflection of the pandemic experience in contagion (an operant conditioning theory criticism)
}

\author{
Mister Gidion Maru*), Sergio Reanaldy Mantouw, Fivy Andries \\ Universitas Negeri Manado, Indonesia
}

\begin{tabular}{l} 
Article Info \\
\hline Article history: \\
Received Aug $25^{\text {th }} 2021$ \\
Revised Sept $12^{\text {th }}, 2021$ \\
Accepted Oct $16^{\text {th }}, 2021$ \\
\hline
\end{tabular}

\section{Keyword:}

Pandemic experience

Contagion

Operant conditioning

\begin{abstract}
This study aims to analyze the reflection on the pandemic circumstances and on the attempts to solve such turmoil as portrayed in the film entitled Contagion. As a sort of literary criticism, this study is qualitative in design. Data collection deals with the use of transcript of the speeches and actions of the characters in particular scenes and certain minutes. For data analysis, this study applies a kind of psychological approach especially Skinner's Operant Conditioning Theory as means of doing the analytical criticism on the film. The analysis results in the findings such as Contagion illustrates the occurrence of the pandemic as indicated by the presence of the pandemic, its victim and spread. Further, the study also reveals that solution for the pandemic can be performed by the government, society, and individual. This study seems to be significant to inspire and encourage solution for the current pandemic condition.
\end{abstract}

(C) 2021 The Authors. Published by IICET

This is an open access article under the CC BY-NC-SA license (https://creativecommons.org/licenses/by-nc-sa/4.0)

\section{Corresponding Author:}

Mister Gidion Maru,

Universitas Negeri Manado

Email: mrgidionmaru@unima.ac.id

\section{Introduction}

Since 2019, the world was shocked by a case of spreading viruses ranging from Wuhan, China and continuing to spread throughout the world. (Hui, et al., 2020). This spread of the virus was later confirmed as a pandemic (Mirza et al., 2021), due to its so rapid and very wide scattering scale (Fahmi \& Wibrianto, 2021). The whole world seeks to research this virus so that information (Yosia, 2021) and solutions from this pandemic can be found, and humanity can be saved from the wide variety of threats caused by this virus (Dharmaraj et al., 2021). During the pandemic period, a great many stories regarding the virus have been raised into a film (Verawati, 2021). In fact, in the case of SARS pandemic in 2003 to 2004 (Da Silva et al., 2021) and a bird flu pandemic in 2009 was raised to a film titled "Contagion" (Daher-Nashif, 2021).

Plague outbreaks clearly impact various aspects of life (Best et al., 2021), which are primarily aspects of health, social, economic, and political aspects (Stawarz et al., 2021). This situation provides security threats to humans, to the country, and globally (Valerisha \& Putra, 2020). The immensely influential impact on humans was lifted in many films so that examples (Umiyanah, 2021), meanings, lessons, and solutions could be taken based on the events and stories that were in those films (Nushur \& Astutie, 2021). In this study, researcher used the "Contagion" movie where "Contagion" is a movie that shows human life (Li \& Zhang, 2021) while being confronted with a pandemic that is widespread worldwide leading (Guo \& Huang, 2021) to the large number of changes in the conditions, human mindset, social activity, economics (Kazantseva et al., 2021), as 
well as everyday life of humans during that pandemic spread (Joelsson \& Ekman Ladru, 2021) and how actions of the authorities as well as the government in addressing the issue.

However, human life before and after the pandemic would have been quite different. During the pandemic, the survivors must face great changes in their lives in order for them to continue to survive and live new lives and situations in their activity. In this movie, the characters made it through pandemic times and led the researcher to be interested in taking the conclusions and solutions of the film, then applying the results of this study to the real world so that the pandemic period in the world could be passed through well. This research aim to find the solutions for pandemic survivors as reflected in this "Contagion" movie and will be delimited only to several characters who survived the conditions of pandemic, the solution, and how the development of the people lives after the disaster in the movie Contagion. Researcher believes that the results of this study can help other research processes as a second source for other researchers, sources of information for readers, and sources of knowledge for other literary enthusiasts.

\section{Method}

In this research, we will use qualitative method. Creswell (1994) states that Qualitative research is the process of inquiry into understanding based on different traditions of methodological inquiry that explore social or human issues. We build complex images, analyze words, report views on detailed information, and conduct research in natural settings.

Based on the above understanding, this research is presented with text analysis, and details are reported from the situational data in the Contagion movie, also the methods used in this study are spelled out into steps according to the implementation stages, namely (1) the data supply stage, (2) the data analysis stage, and (3) the presentation stage of data analysis results.

The data was taken based on the researcher's goals, focused on the pandemic, and the solution while the pandemic spread across the world. The analysis refers to printed materials, images, literary works, film, or other types of record (Creswell, Qualitative Inquiry \& Research Design: Choosing Among Five Approaches). Based on the reference above, to collect the data, the researcher involved the following steps: 1) Understanding and identifying the Pandemic situation in the movie; 2) Watch Contagion, noting the scenes, situations, and actions of the people while facing the Pandemic situation; 3) Collecting support data from various sources; 4) Analyzing data that has been collected to accomplish the purpose of the study, managing data, and making final results.

The data were obtained from primary and secondary sources. The primary sources are the literary work itself, in this case the "Contagion" movie. The secondary sources included articles, e-journals, books, and some other references that related to the movie and the title to support this research.

The data obtained are analyzed using psychological approach that analyze factors and situations that affect the character. Burrhus F. Skinner (1938) states that Psychology deals with the responses to any and every kind of situation that life presents. By responses or behavior is meant all forms of processes, adjustments, activities, and experiences of the organism. The main focus in the study was on how researchers looked at the actions performed by the characters present in the film, and saw the results of the act so as to find solutions from the results that the characters had come up with.

In relation to this study and approach, the researcher used Operant Conditioning Theory where, according to Skinner, Operant Conditioning Theory is a method that uses reward and punishment as a consequence of a behavior. By this method, people who study it will understand the relationship made between behavior and consequences. the Operant Conditioning theory deals with the behavior of a person learned through the practice between reward and punishment, and relying on a simple premise that is, the Action followed by reinforcement or reward will be more likely repeated in the future, whereas actions that exert a negative impact or punishment will tend to be avoided and not repeated.

\section{Results and Discussions}

The pandemic period is identical with pain, fear, and lethal illness. Social life during the pandemic period is indeed a life that no one wants. Nevertheless, there are certainly steps to prevent and protect themselves during pandemic times. Social Distancing, Isolation, Quarantine, and Self Prevention is shown so clearly that a widespread virus can be dealt with immediately. In this film, The Operant Conditioning Theory was used as a theory of reference, which examines as to how the Punishment and Reward systems were featured in the film. The actions performed by the figures are determined by their mindset against the results they will get so that 
the choices and decisions they make will result in answers in the form of solutions that relate to the main focus of the study.

\section{The Pandemic Situation}

In this film, a pandemic atmosphere is shown from the beginning of spreading to the end where a vaccine from the spreading virus is eventually found. The atmosphere experienced and felt by the characters present in the film is shown so well that tension can be instantly felt. The situation in the film is a situation similar to the situation experienced by the world today. The COVID pandemic that spreads around the world and attacks everyone is very similar to the pandemic shown in the film as supports by Dr. Suhail Rub in his journal "The movie rightly insinuates the present global situation and reasserts the plight of human nature where a microscopic organism plays its game." (Rub, 2020). The similarity can be seen in some of the aspects such as the spreading virus, the conditions of the victims, the Health Protocol, Government handling measures, and to the action taken by the public displayed in a structured and clear manner.

\section{The Spread and The Victims}

Viruses are a hot topic in research since 2019. Since the widespread COVID-19 pandemic in the world, research on viruses and their treatment has begun broadly worldwide. In literary development, viruses have historical records ranging from past times, so many films that lift viruses as the main topic in their stories. One of the examples is the "Contagion" Movie.

The spread of the virus and the victims constitute two very related things, whereby the victims of a virus are an impact of the spreading virus. The virus in the film is a highly contagious, lethal, and a new type of virus so that the medicine and vaccines for the virus have not been discovered. The spread from the virus in the film is shown very clearly through the symptoms of the disease experienced by the characters who were victimized by the viral malignancy. Zilinskas states that "viruses are spread person-to-person via airborne droplets produced by sneezes or coughs, as well as by viruses deposited on "fomites"-e.g., doorknobs, peanuts, shared utensils, and so on" (Zilinskas, 2020). This statement suggests that the pandemic situation in the film and currently pandemic in the world designates the spread of the virus through vulnerable media.

In this film, the spread of disease is first shown at the beginning of the film where it is seen some people experience symptoms of disease that are generally just ordinary diseases. As time went on, the victims who showed symptoms eventually died with almost similar traits. At the minute 00:18:44 of the movie, it shows one of the characters in this film that is Beth Emhoff. Beth Emhoff was the wife of Mr. Emhoff, who had just finished traveling from China, and returned home sick. Mrs. Emhoff having a seizure shortly after she is taken to hospital by her husband and the doctors didn't know what disease Mrs. Emhoff had experienced until she died at last. As W. Joost Wiersinga mention on his article, The main symptoms of the virus are usually fever, cough, dyspnea, headache, sore throat, and rhinorrhea. (Wiersinga, Rhodes, Cheng, Peacock, \& Prescott, 2020). Symptoms inflicted by the virus can usually be directly identified based on existing traits. This is the result of records owned by the medical personnel. However, in this movie the spread of this virus has not been clearly shown because at the beginning of the film, the spreading virus has not been successfully identified.

Shortly after Mrs. Emhoff's death, her son Clark who also had symptoms of a similar illness suddenly died mysteriously. The WHO later got a report on a disease spread from China. At the Minnesota Department of Health, Dr. Mears gave her opinion as in the statement at minute 00:17:58.

Dr. Mears: "Three to five times every waking minute. In between, we're touching doorknobs, water fountains, elevator buttons, and each other. Those things become fomites." (Minute 00:17:58, Contagion Movie, Scott Z. Burns, 2011)

Dr. Mears explains that this spreading disease is a respiratory disease, so that one's chances of contracting will be enormous when one is doing an off-home activity. Touching objects in public places as well as touching faces without washing hands is a media of dispersal from the virus. It is also explained that these respiratory diseases are contagious and can attach to the surface of objects touched by the sick. The case in the film has something in common with the case of the world pandemic. Ray Faradillahisari N in his journal mentions that Most corona viruses spread like other viruses in general, such as through the splash of sloppy saliva (cough and sneeze), Touching the hands or faces of infected people, Touching the eyes, nose, or mouth after holding the items affected by the splash of saliva of the corona virus, or feces. (Faradillahisari, 2020). The above quote explains that the transmission of the virus that spread from the film bears some resemblance to the corona virus in the real world. A person with high alert levels to things around them is likely to be harder to get infected with the virus.

People who have disease symptoms and are still doing some activity outside the home are a major problem in the spread of viruses. On one of the scenes in the movie, Dr. Mears having conversation via phone call with 
Mr. Barnes where Mr. Barnes was the one who picked up Mrs. Emhoff at the airport after she traveled from China.

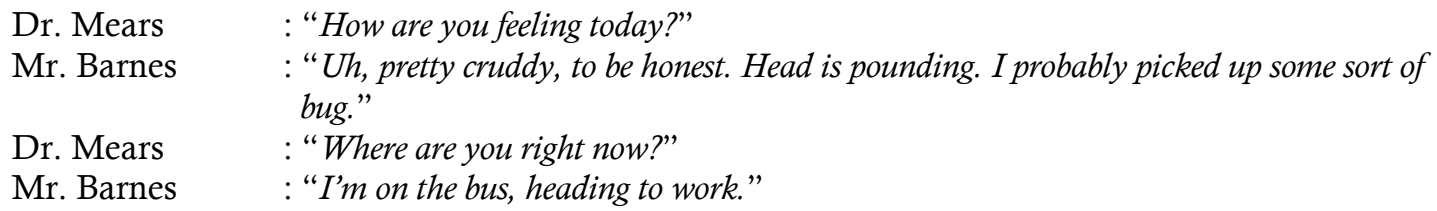

In this scene, Mr. Barnes exposes the symptoms of a disease in the form of a cough, so that Dr. Mears feels confident that Mr. Barnes has been exposed to the disease, and rushes to fetch him immediately. The scene in the film shows Mr. Barnes who is on the bus and holding various objects that are there including seating and handle posts on the bus. It is supported by theories from Faradillahisari i.e., If the infected person still remains working, going to school, attending seminars, or attending music concerts. Although initially the infected one person, but after spreading, it could have been thousands of other people who were in the place, also infected. (Faradillahisari, 2020). This shows that victims who have symptoms accidentally touch objects in public places, so the risk of spreading from the disease to still healthy people become very high. The touch and the liquid particles from the cough could increase the chance of the viruses spreading.

The spread of the virus continued until Dr. Mears who woke up in the morning with a sick state, immediately called Dr. Cheever to inform him of her condition. The victims of this virus including Dr. Mears were treated at a special location built to isolate the victims until minute 01:02:04, shows medical and military personnel who are making mass funerals for victims of the virus. The victims were wrapped in plastic, and buried simultaneously in a vast field. The medics were also shown using very tight security supplies. The actions taken in handling the victims in the film are supported by O'Keffe theory i.e., temporary measures necessary to prevent disease transmission from deceased victims during the pandemic include precautions associated with victim contact and minimize possible exposure to droplets and body fluids by reducing handling of the body directly where possible. (O'Keeffe, 2020). The victims who were stricken with the disease could only attempt to survive with existing medicine while waiting for vaccines and proper treatment from the government. Unfortunately, the disease strikes them so quickly that most of them all end up deceased.

Widespread deployment resulted in the large number of people contracted that the hospital did not have enough room to accommodate those victims as seen at minute 01:16:30 on the movie. This scene shows Dr. Ally who came to a hospital where his father was being treated. He passed a hallway in the hospital and it shows a lot of patients were not in the room because the room in the hospital had been filled. The sick people were lying in the bed of the Aisle. The victims of this virus are treated by medical personnel with complete equipment for the spread of the virus to be stopped.

The situations of the victims caused by the very rapid spread of the virus, exposing a very frightening condition. The situations that occurred in the film along with the victims bears an enormous resemblance to the events that occurred in the real world today. The COVID-19 pandemic that occurs around the world is plague very widely and already takes great fatalities. As we can see from the dialogue and descriptions of some of the scenes above, the act and situations of the victims in this movie is very similar to the situation of the world right now. These similarities are the references in research to finding reflected solutions from films, so researchers can find answers of the questions that can help the world today.

\section{The Attempt to Anticipate the pandemic}

Solutions are the answer that people in pandemic times are highly expected to find, where solutions can only be found when appropriate precautions are taken. Precautions are a step for a person or civic group to be spared from the virus that is being plagued. Precautions are categorized into two parts, which are precautions from the government, and individual precautions.

The act of precaution is the key to finding a reflected solution in the film. By looking at the right precautions, the study could come up with solutions so that the goals of the study could be met. It is this solution that would later be beneficial to apply to the real world, where the conditions drawn on the film have similarities to the conditions that exist in the real world today.

\section{Government initiated Solution}

The government holds a crucial role in maintaining the safety of the existing people, whereby the actions and policies that the government takes greatly affect the people's opportunities to survive the pandemic. Basically, governments must have the goal of protecting the public regardless of their obligations in managing many aspects and fields of the structure of their ministry. Pandemics that attack the public result in the large number 
of policies that the government should take in order for their society to be saved. It is this policy that will later give rise to a solution so that the pandemic can be resolved. Published in National Strategy for the COVID-19 Response and Pandemic "The ability to quickly test, contact trace, isolate and quarantine as appropriate is a linchpin in the work to contain the virus and stop community spread". (Makruf \& Ramdhan, 2021). This supports the need for initiation from the government for solutions to address pandemics such as quarantine. The policy of quarantine and isolation from the government held a significant role in countering the spread of the outbreak.

Quarantine is a form of separation and movement restriction from people potentially affected by infectious diseases and to ensure whether they are healthy or unhealthy, thereby reducing the risk of spreading from a disease. Quarantine is usually done when a place or region has a potential status of spreading on a wider scale. Restrictions of activities in an area are performed in order to avoid the spread from viruses to other regions.

In this film, steps to quarantine the spread of the virus are widely featured in several scenes. At minute 00:12:48, Dr. Cheever states about a case in Hong Kong as follows:

Dr. Cheever : "They're using the same protocols established for SARS. They Quarantining the complex and screening for symptoms." (Minute 00:12:48, Contagion Movie, Scott Z. Burns, 2011)

Quarantining and screening for symptoms was a correct decision since the virus could spread out if they're not taking the case seriously. The scene in the movie also shows the officer performs several precautions that include wearing masks for the patient, measuring body temperature, and documenting the quarantine process. Steps performed are supported by Giriyanna Gowda statement i.e., Contact tracing is the process of identifying, assessing, and managing people who have been exposed to patient to prevent onward transmission. (Gowda, Holla, Ramraj, \& Gudegowda, 2020). Contact tracing was done to search and organize people suspected of having made contact as well as having high risks of exposure to the virus in a location of virus spread.

Quarantine is also performed not only on areas where the virus is found, but for people suspected of making close contact with the victims. This scene is shown at minute 00:15:59, where Jory Emhoff, daughter of Mitch Emhoff, was visiting her father in the hospital.

Doctor : "Your Dad is in Isolation. You can go up the window, you can pick up the phone and you can talk to him."

Jory Emhoff : "Hey, dad. Are you sick?"

Mr. Emhoff : "No, no, uh, it is all just, you know, a precaution, you know, just making sure."

(Minute 00:15:59, Contagion Movie, Scott Z. Burns, 2011).

The dialog above shows that Mr. Emhoff who is suspected of having made close contact with his wife who was a victim of this virus was instantly quarantined in a hospital in order to prevent the virus from spreading, but Mr. Emhoff confirms to his daughter that he is not ill and the medical personnel are only taking precautions. The actions performed by the medical personnel in the film are supported by Giriyanna Gowda statement i.e., Quarantine is the separation and restriction of movement or activities of persons who are not ill but who are believed to have been exposed to COVID19 cases, for the purpose of preventing transmission of diseases. (Gowda, Holla, Ramraj, \& Gudegowda, 2020). This explains that precautions are taken to people who have no symptoms of the disease, as previously Mr. Emhoff had made contact.

Precautions are also taken by the government by closing public place access like schools previously found victims of the virus, as in the scene at minute 00:23:41.

Newscaster: "Government officials are reporting the closing of Mondale Elementary School in suburban Minneapolis in response to the recent outbreak of a still unknown disease that has so far taken the life of a school nurse and three students." (Minute 00:23:41, Contagion Movie, Scott Z. Burns, 2011).

The government took steps to close the school in order to stop the spreading and maintain the safety of the children there. This step is supported by a theory from Abidah where, closing schools or switching to online classes are one of the examples of social distancing regulations. (Abidah, Hidaayatullaah, Simamora, Fehabutar, \& Mutakinati, 2020). This move is an appropriate step because children are highly vulnerable targets of disease, due to their still not fully strong body immune system.

As the outbreak began to spread to various existing places in an area, in addition to quarantining a place and public facilities, the government also carried out quarantines on a wider scale that is quarantine of a city or county. This scene could be seen in the dialog at minute 01:00:02.

$\begin{array}{ll}\text { Mr. Emhoff } & \text { : "We're just trying to get to Wisconsin." } \\ \text { Border Officer } & \text { : "The border is sealed, The Governor has declared a quarantine, get back to your car." }\end{array}$ 
Mr. Emhoff

Border Officer
: "No, we don't want to go back there. We want to go across."

: "Sir, there is no way to get across. Get back in your car or I will detain you."

(Minute 01:00:02, Contagion Movie, Scott Z. Burns, 2011).

The dialog above shows communication between Mr. Emhoff and a security officer on a closed bridge. The officer was seen to ban Mr. Emhoff from leaving the area because the government has been quarantining the area where the community in an area is prohibited from exiting so that the viruses in a region do not spread out. The officer even took a firm step where he said he would detain Mr. Emhoff if he insisted to get out of the city. The above quote is supported by a statement from Aviariska i.e., In regional quarantine, people are not allowed to go outside the house at all, certain activities is constrained such as schools and workplaces, restrictions on religious activities, public place activities, sociocultural activities, restrictions on public transportation tools, and other activities specifically related to aspects of defense and security (Aviariska, 2020). This action is an appropriate action in stopping the process of spreading viruses in the city. The same act is also carried out by the governments and countries of the world today, where there is a ban on traveling outside the regions and countries. This was done so that the government could easily address the pandemic problems that existed in their respective regions and stop the spread between the peoples.

In addition to Quarantine, the Government also took another step that is isolation. Isolation refers to the separation between sick people due to the symptoms of infectious diseases with the aim of protecting uninfected people. Isolation is divided into two types that are isolation done in hospitals, and isolation done independently at home. It is recommended that patients who are being isolated, facilitated with air-pressure rooms with airborne-droplet-contact precautions in order to prevent transmissions via aerosols. (Marchand, et al., 2020). Infected people are usually isolated in a specialized room and directly addressed by medical personnel, so that development from such patients can continue to be monitored and the virus from the person will not spread out.

In this film, the isolation carried out by people contracted by the virus, is supported by the government, whereby the government provides facilities such as special buildings when the hospital is filled with patients. The scene at minute 00:39:00 shows a statement carried by Dr. Mears when she set up a building for the patients.

Dr. Mears : "Okay, we'll put the airlock here, I want 25 rows with 10 beds apiece. The most febrile cases at this end. We'll set up a triage outside, FEMA can handle food in the basement and we'll need to be operational within the next 24 to 48 hours."

Dr. Mears who represents the government and CDC, prepares the building for patients to be isolated. The building, which had previously been a basketball court, was converted into a place to isolate victims who had symptoms of disease from this virus. The hospital was already unable to accommodate the patients so the government built and provided other purposeful places to isolate the infected victims. The reserved premises also have a complete facility which is equipped with airlock, bed, limiting bulkhead, security, and food. The government has an important role in providing existing facilities as described by Riyanti Djalante i.e., Increasing the number of hospitals adequately and equipping those hospitals for treatment properly includes to properly regulate care facilities, diagnostic facilities, medicine and pharmaceuticals, management, medical doctors, specialists, nurses, health volunteers, and safety equipment and protection for frontline practitioners. (Djalante, et al., 2020). This shows that by preparing all the facilities, the government made handling efforts to keep the virus from spreading more and more in the community. After exposed by the virus, was also treated in this place and isolated along with the other patients.

Basically, the actions of the government to counteract the outbreak of the disease are huge, whereby the government issues many policies and regulations in order for the public to survive. The actions taken in the form of quarantine and isolation accompanied by punishment for those who commit offenses constitute proper action in stopping the spread of the disease. Quarantine or often referred to by the term Lockdown constitutes a restriction of community activeity during the day and night. Desi Sommaliagustina explained that lockdown is a government policy to quarantine and close a country or region, closing almost every public place facility, and closing public transportation service including airport. (Sommaliagustina, 2021). This is a solution that can be taken from the film, to be applied in the real world. Action that results in positive impacts will tend to be repeated so that society can avoid disease, whereas actions that can result in negative impacts, will be avoided.

\section{Individual and Society initiated Solution}

It is unquestionable that the government takes a significant role in addressing the problem of spreading viruses on the people. But, the efforts of society and oneself are also no less important, given that everyone's safety depends on the way people make decisions in the interests of everyone and their self. Besides quarantine in 
hospitals and government-provided places, society is also expected to make preventions for themselves, one example i.e., social distancing dan self-prevention. Social distancing (also known as physical distancing) is designed to minimize interaction between people living in a wide community, whereby an individual has a higher tendency to transmit diseases but has not been successfully identified so as to have not been isolated (Mack, Choffnes, Sparling, Hamburg, \& Lemon, 2007). This explains that in a social community, the risk of spreading from the virus will be so high that keeping distance is a way to avoid widespread of the virus.

The Canadian Public Health Agency, indicating that the Social Distance refers to changes to daily routines of a person, to minimize contact directly with others, including to avoid crowded places and unimportant meetings, avoid commonly used greetings such as handshake, limit contact with people who have higher risks, avoid touch against objects used in the public, and avoid touch against faces especially eyes, nose, and mouth. (The Canadia Agency for Public Health, 2020). This explains that to inhibit the spread of viruses, societies are recommended to reduce all sorts of social and physical contact with others so that viruses cannot spread from one to another.

In this film, social distancing is done by most of society because it has been an intuition of humans to avoid things that could harm their self. This mindset was based on their fear of how the dangerous effect could face them when they're infected. This mindset also supported by the government and medical institution through announcement in the media. Dr. Cheever explains at minute 01:04:02 about how someone can take care of their self.

Dr. Cheever : "But right now, our best defense has been social distancing. No handshaking, staying home when you're sick, washing your hands frequently." (Minute 01:04:02, Contagion Movie, Scott Z. Burns, 2011)

By keeping their distance, and not making physical contact with others, Dr. Cheever believes that these actions could prevent the expose of the virus to the body. This TV-broadcast interview not only aims to spread information through the media, but rather also to add to the public's vigilance about the importance of keeping their self from contracting diseases. The above statement is supported by Syarifuddin Akbar in his quote i.e., Amid the threat of a pandemic, mass communication was indispensable to provide education against the wider community. With mass communication, the target of the information provided would be very wide and reach many people at once. (Akbar, 2021)

Social distancing is also performed by Mr. Emhoff when Andrew comes to his house as in the dialog at 00:45:54.

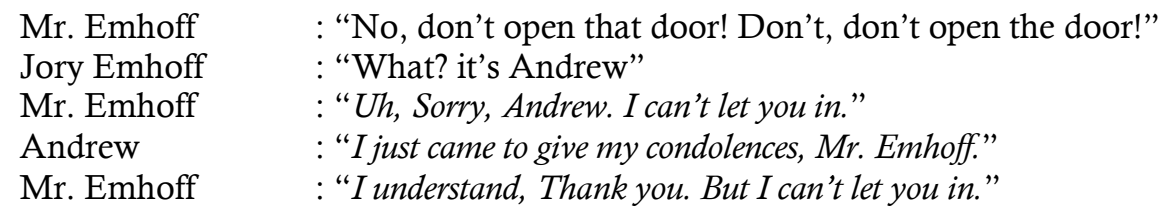

It can be seen in the dialog above that Mr. Emhoff did not allow Andrew who was Jory's boyfriend to come bring flowers due to Mrs. Emhoff's death. This action proves that Mr. Emhoff limited contact between his family with outsiders, whereupon Mr. Emhoff told Andrew to go home and bring the flowers he wanted to give. This action was an act that had a major impact because Mr. Emhoff did not know whether or not Andrew had been exposed to the virus, and whether the objects he touched were also exposed to the virus. Mr. Emhoff took precautions by restricting others access to his home.

The act Mr. Emhoff took was an appropriate act and supported by Fahim Aslam in his statement i.e., social distancing allows individuals to keep their distance from each other for a period of time to ensure the spread of disease is minimized. This will reduce the basic reproductive number (R0) of the virus that will minimize the spread of the disease. (Aslam, 2020). Precautions minimizing the level of virus spreading are actions that everyone should take in order for the spread of the virus to be immediately stopped.

In addition to social distancing, other actions that society can take i.e., Self-prevention. Self-prevention is a form of prevention committed by the private of the joint in order to prevent virus contamination. It requires full awareness of the public to keep them from contracting, or to injure others. To prevent the transmission of the virus, maintain hand hygiene by using hand sanitizer if the hand does not look dirty, or wash the hands with soap if the hands look dirty by clearing the surface of the air-exposed hand using soap. Preventing shakehands also needs to be done to prevent the hand that may just be contaminated by viruses in contact with sensitive organs such as the mouth or eye that can cause viral infections to enter the body. Additionally, measurements of body temperature are inevitable, especially for people who will travel. The detected body temperature exceeds the normal temperature of $38^{\circ} \mathrm{C}$, can be confirmed to have symptoms and must be 
isolated immediately. (Za, Putra, Sofyan, \& Bimo, 2020). Self-prevention which the characters in this film do, one of them can be seen at minute 00:59:00.

Mr. Emhoff : " "Take your gloves off. Here, give me your hands. Now really rub this in."

(Minute 00:59:00, Contagion Movie, Scott Z. Burns, 2011)

At this scene, Mr. Emhoff tells his daughter to immediately use the hand sanitizer shortly after they exit a store. It was seen at the scene that Mr. Emhoff was very careful of the situations surrounding them; that they would not be exposed to the virus that could stick past touch. Prevention in the film has similarities to the prevention described by Juwita and Napitupulu in their journals regarding COVID-19 Pandemic i.e., to break the chain of transmission, a new behavior which is wearing masks, washing hands frequently with soap, maintaining a minimum distance and avoiding crowds of people. (Juwita \& Napitupulu, 2021). Precautions in the form of using hand sanitizers, washing hands, wearing masks do look to be very small, but the resulting impact is enormous. In the thought of a person who cares about his health, reward and punishment which they will receive tends to be thought through maturely because someone will definitely choose precautionary measures to keep their self from contracting the virus. Using hand sanitizers, their hands originally used to touch dirty objects and with a high likelihood of containing viruses can be averted.

In addition to using hand sanitizers, wearing masks and checking body temperature in public places is also a very precise action. It can be seen at minute 00:31:41 where it shows two employees who are at an airport in Hong Kong using masks when they are in the act. On the scene it was also seen most of the people are using masks while they're travelling, but many people are unconcerned and still doing activity without proper safeguards. It is this behavior that society in the world often shows, where they don't care about the circumstances around them, so that they are the ones that are the main causes of spread from viruses, are very difficult to stop. Joko Tri Atmojo in his conclusion explains that Masks can protect against coarser droplets and finer transmission of aerosols, so the use of masks in an attempt to prevent viral transmission is indispensable. Various studies have proven the effectiveness of masks in preventing respiratory infection diseases. (Atmojo, 2020). Various policies regarding prohibitions for people who do not use masks in public places are already implemented, but these are mostly not obeyed.

These actions are often ignored by people due to the lack of high vigilance and self-confidence that they are immune to spreading diseases, causing the difficulty of stopping the widespread outbreak in society. Keeping distance, washing hands, and using masks, are an early step that society can take in order to keep themselves from being exposed to dangerous viruses. These three things do not indeed guarantee $100 \%$ that a person will not be exposed to the virus, but this does minimize the possibility that a person is prone to contracting the virus.

\section{Film/News as Information Spread Device}

Films constitute literary works reflecting on messages and solutions, having a great deal of usability. Film as a mass media format in addition to functioning itself as a means of entertainment, can also be a medium of learning as well as a process of socialization where value is delivered then absorbed by audiences and there will be an internalization process that then affect people's attitude.

When watching a movie, the audience seemed to be able to penetrate the space and time that could tell life and could even affect audiences. (Baran, 1992). Because basically Film always records a reality that grows and develops within a society and then projects it into the screen. (Sobur, 2006). According to Redi Panuju, film can be a good medium of learning for its audience not solely entertaining, Film is also able to deliver a direct message through images, dialogue, and play so it becomes the most effective medium for spreading missions, ideas, and campaigns, whatever it is. It delivered in his book's event "Film Sebagai Proses Kreatif" at the Wisma Kalimetro (Thursday, November 14, 2019).

Films are often become a tool for their makers to convey the moral message implied to the audience of the film. (Zoebazary, 2010). Film is part of mass media communication with audio-visual and aims to convey a particular social or moral message to its audience.

In this study, film was used as a research object that produced solutions, whereby "Contagion" films were researched in search of solutions reflected in the film. The solutions found in the film are solutions mentioned, described, and performed by the characters present in the film. Not only films, the media of information dissemination was also done by the characters through newscasts and radio.

Newscaster : "Local officials are now saying over 3.000 cases have been confirmed in the western suburbs, as well as the first cases reported in Ramsay, Carlton, and St. Louis Counties, as the virus continues to spread." 
The above statement shows information regarding the spread of the virus broadcast by television. By spreading information over television, the public can know the developments that occur around them more quickly. This statement supported by Abudllah in his journal i.e., Television functions grew wider, which initially only as entertainment media later widened had information and educational functions. (Abdullah \& Puspitasari, 2018). Media such as television are indeed very useful because most societies can access the object and often spend a lot of time on its precipitation, this causes information to be spread very widely and quickly. This action is one of the solutions by which the wider public can know and realize about the precautions they can take.

\section{Health and Social Aspect}

The approach used in this study is the psychological approach, whereby this approach lifts aspect of health. The actions performed by the characters in the film are underlain by their own mindset. In this study, researchers used the Psychological Approach whereby the psychological approach had an important role in research on the nature and behavior of a person.

Health Aspect that affected was how pandemic-impacted societies in the film begin to change their ways and mindsets in protecting their Health. Actions such as using health protective tools, diligent hand washing, using hand sanitizers, and avoiding physical contact with others are the result of society's mindset in protecting themselves from spreading viruses. As Juwita and Napitupulu state in their journals regarding COVID-19 Pandemic i.e., to break the chain of transmission, a new behavior which is wearing masks, washing hands frequently with soap, maintaining a minimum distance and avoiding crowds of people. (Juwita \& Napitupulu, 2021). This precaution is an action that results in positive effects so that the chances of the individual doing this back in the future become very high. These precautions are often viewed as trivial and minor, but the resulting impact is actually enormous. The risks faced are a consideration from a person in taking preventive measures. The result of this action that is, societies manage to protect themselves and survive, so that this can be expressed as a solution in the face of pandemic times.

Furthermore, Social aspect where society is encouraged to reduce social contact with others. These actions are influenced by their thinking on the negative impacts they will receive when they make social contact with others. Social contact in the form of shaking hands, communicating without safety devices, and performing activities with others in public places is an action to be avoided so that the public must accept that their social contacts should be restricted. Sommaliagustina explains that the most important thing to do in the application of social distance is to stay away from any form of sorority, keep distance with humans, and avoid various encounters involving many. (Sommaliagustina, 2021). By doing this, people will tend to think about the impact they will receive when they reduce social contact with others. The fear they have tends to make them become more vigilant that the reward they get from the act is the fact that they will not easily contract the virus.

The government in this regard takes a significant role in issuing policies regarding the social restrictions of the people. Regulations for closing public places, quarantining a region or an area, and restricting community access to interact with others constitute actions committed by the government in this film.

\section{Conclusions}

Humans in their daily life during pandemic times are faced with many choices. The actions taken are determined by how one thinks about the consequences they will result from the act. Instinctively, humans will take actions that they think are actions that positively impact their lives, and will avoid actions that can harm their lives. The study aimed at finding solutions during the pandemic period, by looking at the characteristics of the characters present within the "Contagion" film.

There are several types of solutions featured in this film such as Social Distancing, Isolation, Quarantine, and Self Prevention such as social distancing, washing hands cleanly, wearing security equipment in the form of masks, and using hand sanitizers while in public places. Quarantine is a form of separation and movement restriction from people potentially affected by infectious diseases and to ensure whether they are healthy or unhealthy, thereby reducing the risk of spreading from a disease. Furthermore, Isolation is a further precaution of quarantine to isolation is an act of separation between people suspected of contracting a disease and showing a sign or symptom with a healthy person and is usually done in hospitals with medical personnel ready at all times and done in a closed room and should only be accessed by professional medical personnel.

Social distancing is an act of minimizing interaction between people living in a community, where an individual has a higher tendency to transmit diseases but has not been successfully identified. To inhibit the spread of viruses, societies are recommended to reduce all sorts of social and physical contact with others so 
that viruses cannot spread from one to another. Self-prevention is a form of prevention committed by an individual in order to prevent virus contamination. Preventing shake-hands, staying home when the person feels sick, washing hands cleanly, using hand sanitizer, and wearing masks in public area is a form of selfprevention. Researcher found the effects of the solution applied in the film that most of the characters present in the film could eventually passthrough pandemic, treatment, and vaccines eventually found thanks to much information obtained from research conducted through various Health protocols.

The governments must have the goal of protecting the public regardless of their obligations in managing many aspects and fields of the structure of their ministry. The government is expected to provide many solutions, rules, policies, as well as assistance in order for the public to continue to survive and ultimately pass through the pandemic period well. After the government, Society should be more alert to the circumstances around, whereby societies are particularly vulnerable to exposure to viruses if they are not careful in making decisions for themselves.

\section{References}

Abdullah, A., \& Puspitasari, L. (2018). Media televisi di era internet. ProTBest, L. A., Law, M. A., Roach, S., \& Wilbiks, J. M. P. (2021). The psychological impact of COVID-19 in Canada: Effects of social isolation during the initial response. Canadian Psychology/Psychologie Canadienne, 62(1), 143.

Da Silva, P. G., Mesquita, J. R., Nascimento, M. de S. J., \& Ferreira, V. A. M. (2021). Viral, host and environmental factors that favor anthropozoonotic spillover of coronaviruses: An opinionated review, focusing on SARS-CoV, MERS-CoV and SARS-CoV-2. Science of the Total Environment, 750, 141483.

Daher-Nashif, S. (2021). Doctors' challenges during infectious disease outbreaks: medical education insights from realistic fiction movies. Advances in Medical Education and Practice, 12, 265.

Dharmaraj, S., Ashokkumar, V., Hariharan, S., Manibharathi, A., Show, P. L., Chong, C. T., \& Ngamcharussrivichai, C. (2021). The COVID-19 pandemic face mask waste: a blooming threat to the marine environment. Chemosphere, 272, 129601.

Fahmi, M. Z., \& Wibrianto, A. (2021). KIMIA NANO: Konsep, Sejarah, dan Aplikasinya bagi Indonesia. Airlangga University Press.

Guo, J., \& Huang, J. (2021). Information literacy education during the pandemic: The cases of academic libraries in Chinese top universities. The Journal of Academic Librarianship, 47(4), 102363.

Joelsson, T., \& Ekman Ladru, D. (2021). Cracks in the well-plastered façade of the Nordic model: reflections on inequalities in housing and mobility in (post-) coronavirus pandemic Sweden. Children's Geographies, $1-9$.

Kazantseva, D., Tarasov, S., Medvedeva, I., Tarasova, E., \& Baranova, E. (2021). Moral potential and ecoresponsibility in the modern socio-economic conditions of Russia. E3S Web of Conferences, $258,7019$.

Li, J., \& Zhang, H. (2021). Crowd Evacuation Simulation Research Based on Improved Reciprocal Velocity Obstacles (RVO) Model with Path Planning and Emotion Contagion. Transportation Research Record, 03611981211056910.

Mirza, A. Z., Shamshad, H., Osra, F. A., Habeebullah, T. M., \& Morad, M. (2021). An overview of viruses discovered over the last decades and drug development for the current pandemic. European Journal of Pharmacology, 890, 173746.

Nushur, R. D., \& Astutie, D. D. (2021). Producing Documentary Film As A Project On Project Based Learning Approach In Improving Critical Thinking. JESS (Journal of Education on Social Science), 5(1), 1123.

Stawarz, N., Ette, A., \& Rüger, H. (2021). Healthy Migrants? Comparing Subjective Health of German Emigrants, Remigrants, and Non-Migrants. The Global Lives of German Migrants: Consequences of International Migration across the Life Course, 205.

Umiyanah, S. (2021). Pesan Moral Dalam Film Habibie dan Ainun 3 (Analisis Semiotika Roland Barthes). UIN SMH BANTEN.

Verawati, N. (2021). mewujudkan kemandirian pangan melalui budidaya sayur dengan metode hidroponik (pemberdayaan komunitas remaja putri di panti asuhan Al-Ikhlas Griyomapan Sentosa Kec Waru Kab Sidoarjo pada masa pandemi covid-19). UIN Sunan Ampel Surabaya.

Yosia, B. (2021). Objektivitas Pemberitaan Virus Covid-19 Dalam Okezone.com. Jurnal Komunikasi Dan Kajian Media, 5(1), 1-16.

$V F, 101-110$.

Abidah, A., Hidaayatullaah, H. N., Simamora, R. M., Fehabutar, D., \& Mutakinati, L. (2020). The Impact of Covid-19 to Indonesian Education and Its Relation to the Philosophy of "Merdeka Belajar". Studies in Philosophy of Science and Education, 38-49. 
Akbar, S. (2021). Media communications in supporting dissemination information on the countermeasure of covid-19 pandemic. Majalah semi ilmiah populer komunikasi massa, 73-82.

Alghamdi, A. A. (2021). Impact of the COVID-19 pandemic on the social and educational aspects of Saudi university students' lives. PLoS One, 1-18.

Alwani, D. (2020). Managing work-related psychosocial risks during the COVID-19 pandemic. 1-34.

Aslam, F. (2020). COVID-19 and Importance of Social Distancing. Preprint.

Atmojo, J. T. (2020). Penggunaan masker dalam pencegahan dan penanganan covid-19: rasionalitas, efektivitas, dan isu terkini. Avicenna : Journal of Health Research, 84-95.

Aviariska, A. M. (2020). Regional Quarantine Policy Related to Handling Covid-19 Pandemics in Various Countries. Media Gizi Kesmas, 67-73.

Baran, S. J. (1992). Introduction to Mass Communication: Media Literacy \& Culture. Ohio: McGraw Hill Higher Education.

Djalante, R., Lassa, J., Setiamarga, D., Sudjatma, A., Indrawan, M., Haryanto, B., . . Warsilah, H. (2020). Review and analysis of current responses to COVID-19 in Indonesia: Period of January to March 2020. Progress in Disaster Science.

Faradillahisari, R. (2020). Penanganan Pelayanan Kesehatan Di Masa Pandemi Covid-19 Dalam Perspektif Hukum Kesehatan. Journal Inicio Legis, 1-17.

Gowda, G., Holla, R., Ramraj, B., \& Gudegowda, K. S. (2020). Contact Tracing and Quarantine for COVID19: Challenges in community surveillence. Indian journal of community health, 306-308.

Hui, D. S., Azhar, E. I., Madani, T. A., Ntoumi, F., Kock, R., Dar, O., \& Ippolito, G. (2020). The continuing 2019-nCoV epidemic threat of novel coronaviruses to global health - The latest 2019 novel coronavirus outbreak in Wuhan, China. International Journal of Infectious Diseases, 264-266.

Juwita, C. P., \& Napitupulu, R. M. (2021). Hygiene and Healthy Living Behavior and Stress During The COVID-19 Pandemic. International Journal of Medical and Exercise Science, 1041-1048.

Klarer, M. (2004). An Introduction to Literary Studies. London: Routledge Taylor \& Francis Group.

Lesser, J., Reich, N. G., \& Cummings, D. A. (2009). Outbreak of 2009 pandemic influenza A (H1N1) at a New York City school. New York City Department of Health and Mental Hygiene Swine Influenza Investigation Team, 2628-2636.

Mack, A., Choffnes, E. R., Sparling, F. P., Hamburg, M. A., \& Lemon, S. M. (2007). Ethical and Legal Considerations in Mitigating Pandemic Disease. Washington DC: National Academic Press.

Makruf, A., \& Ramdhan, D. H. (2021). Outdoor Activity: Benefits and Risks to Recreational Runners during the COVID-19 Pandemic. National Public Health Journal, 60.

Marchand, S. X., Kozak, R., Mubareka, S., Salt, N., Gubbay, J. B., Eshagi, A., . . . Leis, J. A. (2020). Diagnosis and Management of First Case of COVID-19 in Canada: Lessons Applied From SARS-CoV-1. Clinical Infectious Diseases, 2207.

Nastiti, R., \& Rusvitawati, D. (2021). Impacts of COVID-19 Pandemic on Employees' Anxiety and Safety Behavior at Higher Educational Institutions in Banjarmasin. INOBIS: Jurnal Inovasi Bisnis dan Manajemen Indonesia, 295-304.

O'Keeffe, J. (2020). Death care during the COVID-19 pandemic: understanding the public health risks. The Journal of the Canadian Institute of Public Health Inspectors, 40-47.

Prakoso, G. (1997). FILM PINGGIRAN : Antologi Film Pendek, Film Eksperimental \& Film Dokumenter . Jakarta: Fatma Press.

Prioleau, T. (2021). Learning from the Experiences of COVID-19 Survivors: A Descriptive Study. medRxiv.

Rub, S. A. (2020). Pandemic Literature: Envisioning Catastrophe in Soderbergh's Contagion. International Journal of English Literature and Social Sciences, 1.

Skinner, B. F. (1938). The Behavior of Organisms. New York: D. Appleton-Century Co.

Sobur, A. (2006). Semiotika Komunikasi. Bandung: Remaja Rosdakarya.

Sommaliagustina, D. (2021). Karantina wilayah berdasarkan undang-undang no 6 tahun 2018 tentang kekarantinaan kesehatan. Gagasan Hukum, 84-100.

The Canadia Agency for Public Health. (2020, April 15). Physical distancing: actions for reducing the spread of Covid-19. Retrieved October 2, 2021, from The Canadia Health Agency for Public.

Torales, J., O'Higgins, M., Castadelli-Maia, J. M., \& Ventriglio, A. (2020). The outbreak of COVID-19 coronavirus and its impact on global mental health. International Journal of Social Psychiatry, 317-320.

Valerisha, A., \& Putra, M. A. (2020). Pandemi Global COVID-19 dan Problematika Negara-Bangsa: Transparansi Data Sebagai Vaksin Socio-digital?

Wang, C. (2021). The impact of COVID-19 pandemic on physical and mental health of Asians: A study of seven middle-income countries in Asia. Plos One, 1-20.

Widianto, R., Warouw, D. M., \& Senduk, J. J. (2015). Analisis Semiotika Pada Film Senyap Karya Joshua Oppenheimer. Acta Diurna, 6. 
Wiersinga, J. W., Rhodes, A., Cheng, A. C., Peacock, S. J., \& Prescott, H. C. (2020). Pathophysiology, Transmission, Diagnosis, and Treatment of Coronavirus Disease 2019 (COVID-19). Clinical Review \& Education, 782-793.

Yudi, L., \& Ibrahim, I. S. (1982). Bahasa dan Kekuasaan: Politik Wacana di Panggung Orde Baru. Bandung: Mizan.

Za, S., Putra, D. I., Sofyan, S., \& Bimo. (2020). Pedoman Umum Menghadapi Pandemi COVID-19 bagi Pemerintah Daerah. Jakarta: Kementrian Dalam Negeri RI.

Zhang, Y., \& Ma, Z. F. (2020). Impact of the COVID-19 Pandemic on Mental Health and Quality of Life among Local Residents in Liaoning Province, China: A Cross-Sectional Study. Interational Journal of Environmental Research and Public Health, 1-12.

Zilinskas, R. A. (2020). Revisiting “Contagion” During A Real Pandemic. Middlebury Institute of International Studies at Monterey.

Zoebazary, I. M. (2010). Kamus Istilah Televisi dan Film. Jakarta: PT. Gramedia Pustaka Utama. 